\title{
Effects of neonatal hypoglycaemia on the nervous system: a pathological study
}

\author{
JOHN M. ANDERSON, R. D. G. MILNER, AND SABINA J. STRICH \\ From the Department of Neuropathology, Institute of Psychiatry, \\ The Maudsley Hospital, Denmark Hill, London, and the Nuffield Neonatal Research Unit, \\ Institute of Child Health, The Hammersmith Hospital, Ducane Road, London
}

Irreversible pathological changes in the central nervous system due to prolonged hypoglycaemia have been described many times in adults (see Lawrence, Meyer, and Nevin, 1942). It is less well known that hypoglycaemia can occur in the neonatal period and that it may be a cause of brain damage at that time.

In full-term and premature babies the normal blood glucose concentration during the first few days of extrauterine life is in the range of 30 to 60 mg./100 ml.; blood glucose levels of less than 20 $\mathrm{mg} . / 100 \mathrm{ml}$. are regarded as abnormal. The first account of infants with abnormal clinical signs attributable to hypoglycaemia was probably that of Hartmann and Jaudon (1937). The importance of the condition was not appreciated until 1959 when Cornblath, Odell, and Levin described eight newborn babies with symptoms due to severe hypoglycaemia, two of whom became spastic and mentally retarded. The eight infants were underweight for their gestational age and had been born to nondiabetic women. Further clinical reports have confirmed that prolonged hypoglycaemia in the neonatal period may lead to death or to survival with mental deficiency and cerebral palsy unless adequate treatment is given (Brown and Wallis, 1963; Cornblath, Wybregt, Baens, and Klein, 1964; Haworth and McRae, 1965). It has also been established that the infants most liable to develop serious hypoglycaemia are those born with poor liver carbohydrate stores, that is, the very premature and those that are underweight because of intrauterine malnutrition (Shelley and Neligan, 1966).

To our knowledge there have been no accounts of the pathological findings in acute or chronic brain damage due to neonatal hypoglycaemia, apart from a preliminary report of our cases 1 and 2 (Anderson, Milner, and Strich, 1966). We now present the clinical histories and pathological findings in six patients, three in whom hypoglycaemia was regarded as the major cause of death and three who died of other causes after the hypoglycaemia had been successfully treated.

\section{MATERIALS AND METHODS}

Blood glucose was estimated by a glucose oxidase method (Stevens, 1965) using umbilical vein blood. Glucose tolerance tests were performed by giving a loading dose of $0.5 \mathrm{~g}$. of glucose $/ \mathrm{kg}$. body weight as a $10 \%$ solution intravenously. The rate constant $(\mathbf{K})$ for glucose disappearance was calculated from the absolute blood glucose values. The normal mean $\mathrm{K}$ value for newborn babies calculated from the data of Baird and Farquhar (1962) is $0.5 \pm 0.19$.

Normal birth weights were taken from the British Perinatal Mortality Survey (Butler and Bonham, 1963) where they are given as the modal value expressed as a range. Normal organ weights were taken from Gruenwald's tables (1963). The ratio of brain weight to liver weight is recorded because this gives an indication of the infant's state of nutrition. After 28 weeks' gestation the brain weighs about three times as much as the liver (Dawkins, 1964). In babies who have suffered intrauterine malnutrition the liver weight is much reduced whereas the brain weight is usually within normal limits. In such cases the ratio of brain weight to liver weight is greater than 3.

HISTOLOGICAL METHODS The brain, spinal cord, and samples from other tissues were fixed in a $4 \%$ solution of formaldehyde in $10 \%$ saline. Blocks were taken from many regions of the cerebral cortex, from the basal ganglia anteriorly and posteriorly, from one cerebellar hemisphere and the vermis, from at least three levels each of brainstem and spinal cord, and from posterior root ganglia. In cases 1,2 , and 5 samples of peripheral nerves and muscles were studied.

Blocks were embedded in paraffin wax, reinforced with $10 \%$ Alston dental wax (Dental Manufacturing Co.) and $1 \frac{1}{2} \%$ beeswax. Paraffin sections were stained with haematoxylin and eosin, haematoxylin and van Gieson's mixture, cresyl violet, Mallory's phosphotungstic acid haematoxylin for myelin and glial fibres, and Gallyas' method (1963) for microglia. Selected sections were stained with Luxol-fast blue for myelin, Holzer's method for glial fibres, Palmgren's method (1948) for 
nerve fibres, and the periodic acid-Schiff technique. Frozen sections from gelatin-embedded blocks were stained with Oil-red-O for neutral fat and with the WeilDavenport method for microglia. In cases 1 and 6 frozen sections from unembedded material were impregnated by Cajal's gold sublimate method for astrocytes.

\section{CASE REPORTS}

\section{UNTREATED PATIENTS}

CASE 1 D. C., MALE (HAMMERSMITH HOSPITAL NO. 298778) Gestation 39 weeks. Birth weight 3,280 g. (normal 3,0003,500 g.). This was the fourth child of a 23-year-old woman. He was born spontaneously by the vertex after a normal pregnancy and was in excellent condition at birth. At 17 hours of age he was noticed to be jittery, that is, he showed irregular limb movements of small amplitude which occurred about 10 times per second. On neurological examination the Moro reflex was found to be abnormal. At $\mathbf{4 7}$ hours of age there were further episodes of jitteriness and there were bouts of bradycardia. Between attacks he was lethargic, limp, and pale. The Moro reflex was now almost absent. At 49 hours of age a series of generalized convulsions occurred, each consisting of tonic spasms involving limbs and face, lasting one to two seconds and recurring several times a minute. The fits continued for 25 minutes and were relieved only by paraldehyde. Afterwards the baby was cold and clammy and showed little spontaneous movement. At 51 hours of age a lumbar puncture was performed. The cerebrospinal fluid was clear and under normal pressure but the glucose concentration was found to be $6 \mathrm{mg} . / 100 \mathrm{ml}$. Blood glucose at this time was $8 \mathrm{mg}$./ $100 \mathrm{ml}$. A glucose infusion was being prepared when the baby had another fit, aspirated some milk and died aged $55 \frac{1}{2}$ hours.

Pathological findings (Maudsley no. 3301) At necropsy, nine hours after death, the trachea was filled with milk curds and haemorrhagic foci were present in each lung, although extensive only in the right lower lobe. The liver was of normal appearance but was small and weighed $96 \mathrm{~g}$. (normal $142 \pm 35 \mathrm{~g}$.). The remainder of the alimentary system, the cardiovascular system, the genitourinary system, the endocrine glands, thymus, and spleen appeared normal. The skull, meninges, and venous sinuses were normal. The brain weighed $430 \mathrm{~g}$. (normal $400 \pm 50$ g.) giving a ratio of brain weight to liver weight of 4.4. The pattern of cerebral convolutions was in keeping with the gestational age of 39 weeks assessed from the menstrual history. The brain showed no macroscopic abnormality and in particular there was no evidence of brain swelling.

Histology The focal pulmonary haemorrhages were subpleural, interstitial, and to a lesser extent intraalveolar in situation. In the liver, the sinusoids were large and the parenchymal cells appeared to have less cytoplasm than normal, although measurements were not made. The thymus, thyroid, adrenal and pituitary glands, pancreas, kidneys, heart, and spleen appeared normal and post-mortem autolysis was not conspicuous.

Acute degeneration of nerve cells and glial cells was found in all parts of the central nervous system. In small nerve cells, the nuclei were shrunken and there was clumping of chromatin. In some, the nuclear membrane had disappeared and the chromatin fragments were either

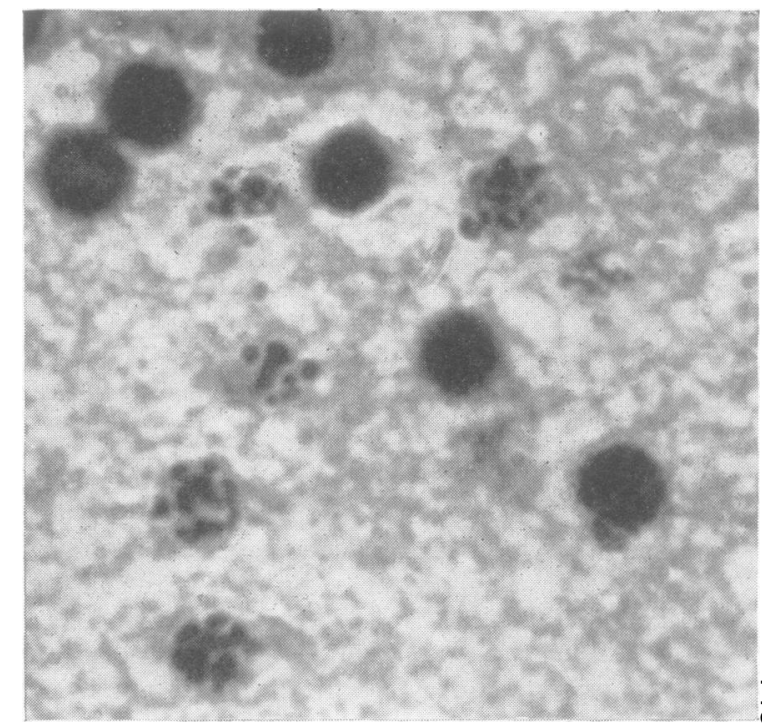

FIG. 1a.

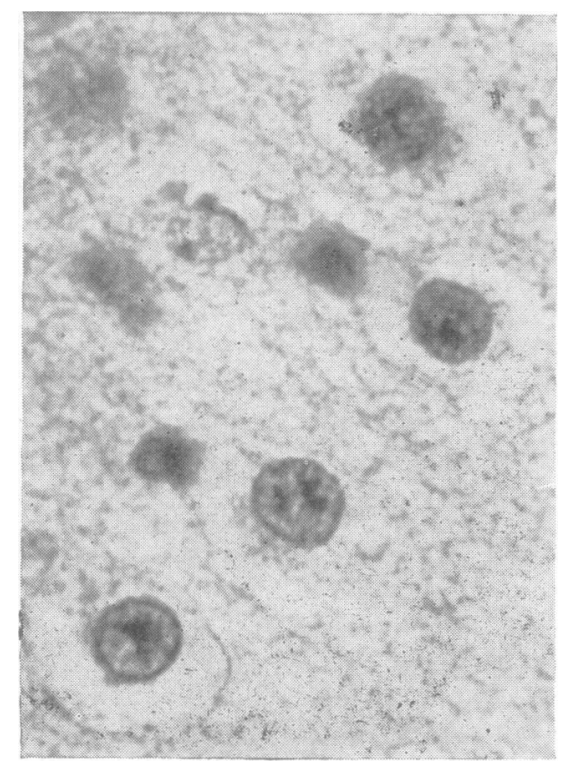

FIG. $1 b$.

FIG. 1a. Case 1. Occipital cortex. The nuclei of some nerve cells are pyknotic and others are fragmented. Compare with Fig. $1 b(H \& E \times 1,800)$.

FIG. 1b. Normal cerebral cortex in an infant of 40 weeks' gestation. Notice the lightly stained chromatin of the nuclei and the well formed nuclear membrane ( $H \& E \times$ 1,200 ). 


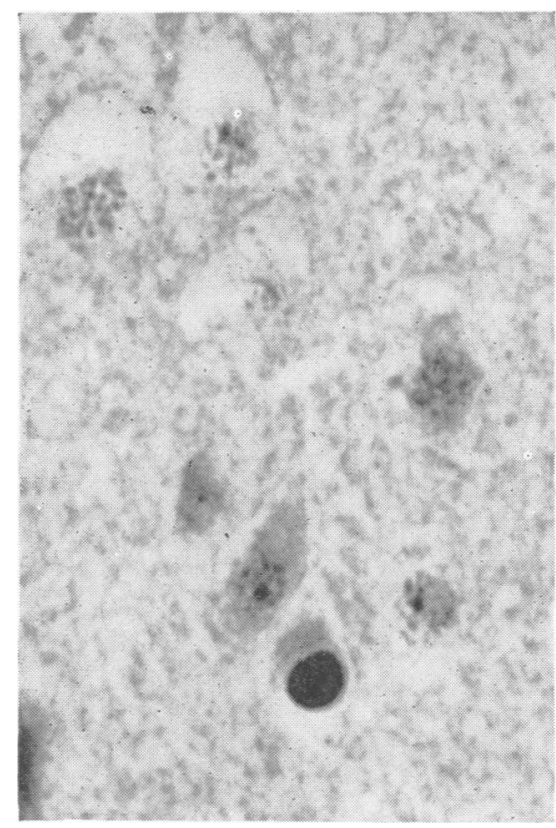

FIG. 2. Case 1. Putamen, showing clumping of chromatin and nuclear fragmentation in nerve cells $(H \& E \times 1,200)$.

scattered in the cytoplasm (Fig. 1) or had aggregated to form a beaded pyknotic mass. In infants, most of the nerve cells in the cerebral cortex are small, and abnormal nuclei were seen in a large number of such cells in all cortical regions. The changes were most severe in the occipital lobes and least marked in the temporal lobes. All layers of the cortex were affected and there was no selective laminar involvement. The cortex at the bottom of sulci and at the boundary zones of the territories of the major cerebral arteries was no more abnormal than that elsewhere. Moderate numbers of abnormal nuclei were present in the endfolium, in the fascia dentata, and in the pyramidal cell layer of the hippocampus. Fragmented nuclei were almost universal in small and large neurones of the caudate nucleus, the putamen (Fig. 2), and the claustrum, and were plentiful within the internal granular layer of the cerebellum. There was no obvious cell loss either in the cerebral cortex or elsewhere.

Another type of degenerative change was found in large nerve cells. In these there was chromatolysis with swelling and granularity of the cytoplasm (Figs. 3, 4, 5, and 6). The nuclei were smaller than normal, opaque, often finely stippled, and some showed loss of basophilia. They were frequently surrounded by a pale zone. Nuclear fragmentation was seen only occasionally in large neurones. In some situations, notably the anterior horn of the spinal cord, large cytoplasmic vacuoles were seen. Some of the large pyramidal cells of the cerebral cortex showed chromatolysis and pyknosis of the nucleus. Most of the large nerve cells in the thalamus (Fig. 3) and hypothalamus and in the globus pallidus were involved, as were the Purkinje cells (Fig. 7) and neurones of the deep cerebellar nuclei. In the brainstem severe change was seen in all the nerve cells in the motor

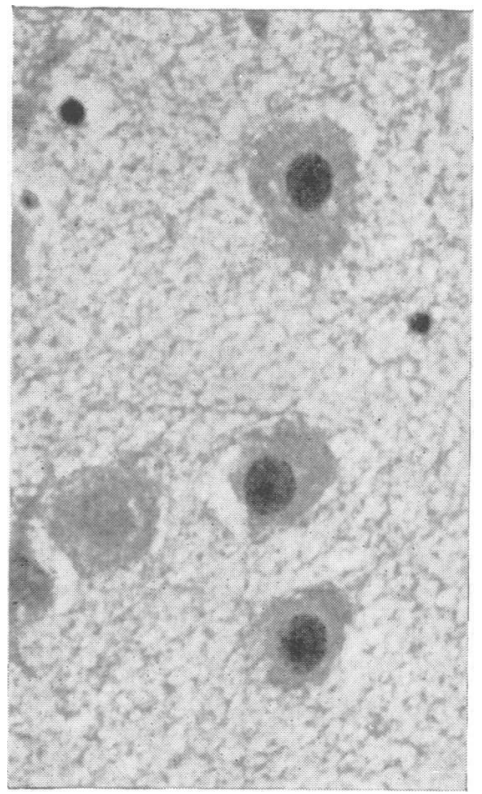

FIG. 3a.

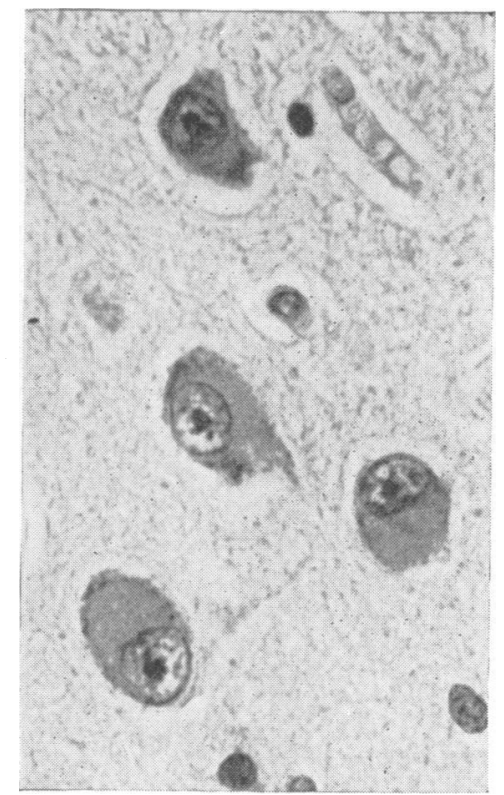

FIG. 3b.
FIG. 3a. Case 1. Thalamus. The large nerve cells are chromatolytic and have pyknotic nuclei. In one nerve cell the nucleus shows loss of basophilia. Compare with Fig. $3 b$ $(H \& E \times 600)$.

FIG. 3b. Normal looking nerve cells in the thalamus of an infant of $\mathbf{4 0}$ weeks' gestation. Note the large vesicular nucleus and peripherallyplaced Nissl bodies $(H \& E \times 600)$. 


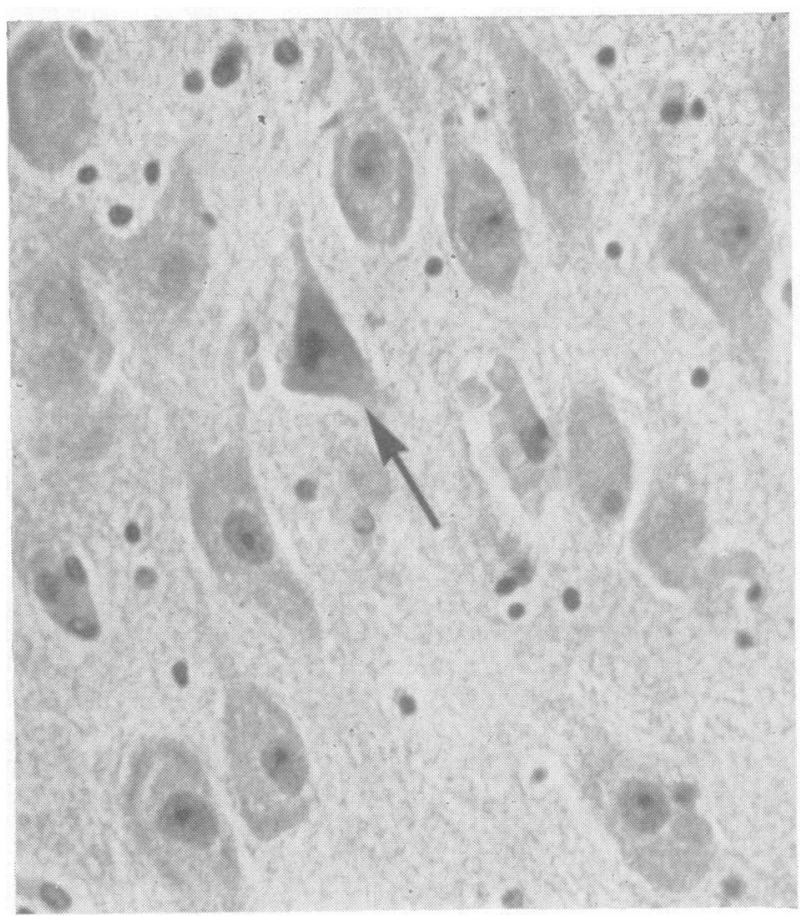

FIG. $4 a$.

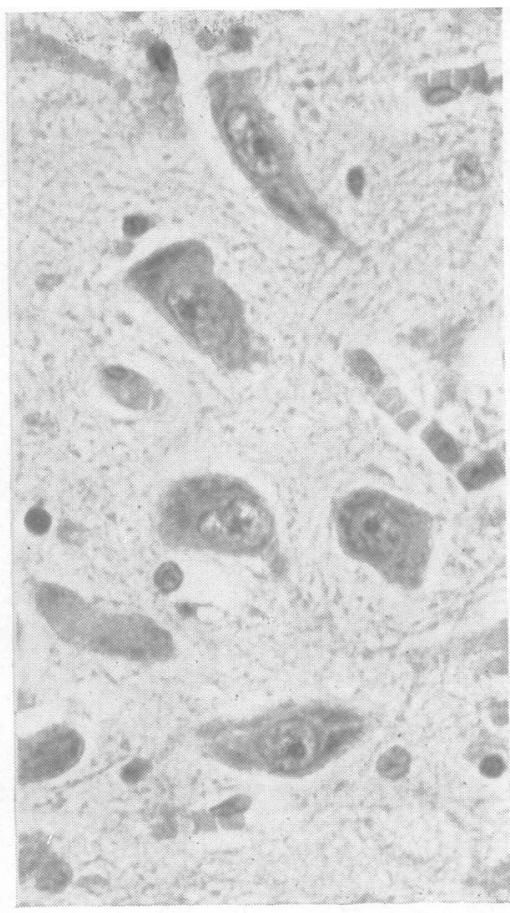

FIG $4 b$.

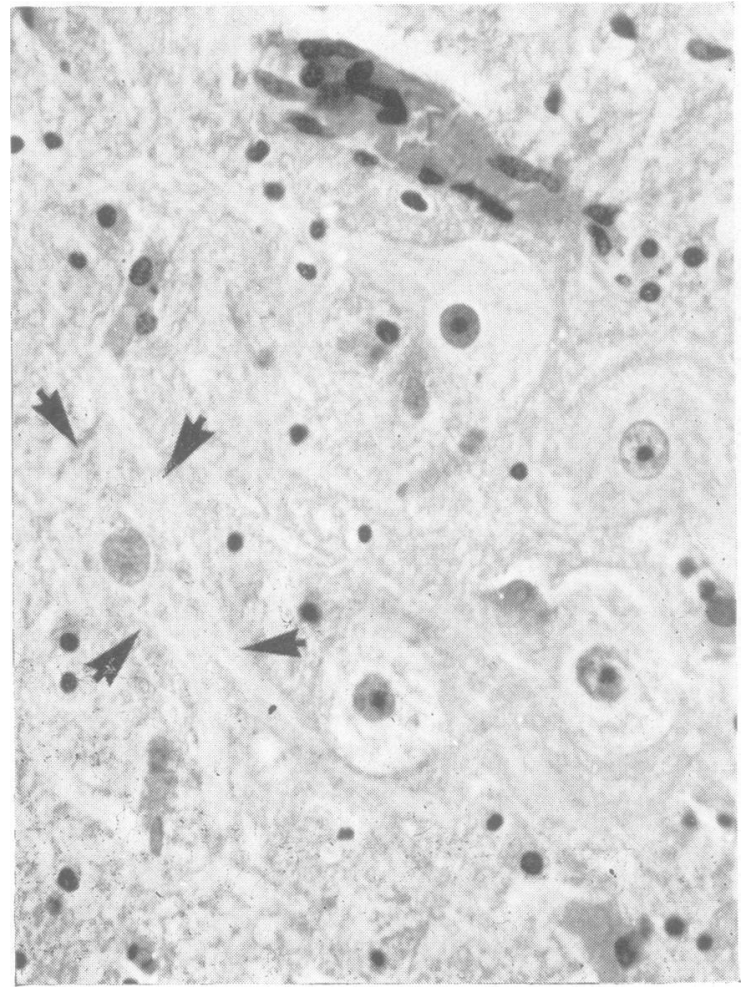

FIG. 4a. Case 1. Substantia nigra, showing nerve cells with ill-defined Nissl bodies. The nuclei are smaller and denser than normal. One 'ischaemic' nerve cell is shown (arrow). Compare with normal substantia nigra from an infant of 40 weeks' gestation in Fig. $4 b$. ( $H \& E \times 480)$.

FIG. 5. Case 1. Motor trigeminal nucleus. The motor neurones show advanced chromatolysis and have pyknotic nuclei. One 'ghost' cell is seen (arrows), with faintly staining nucleus and Nissl bodies ( $H \& E \times 480)$.

FIG. 5. 

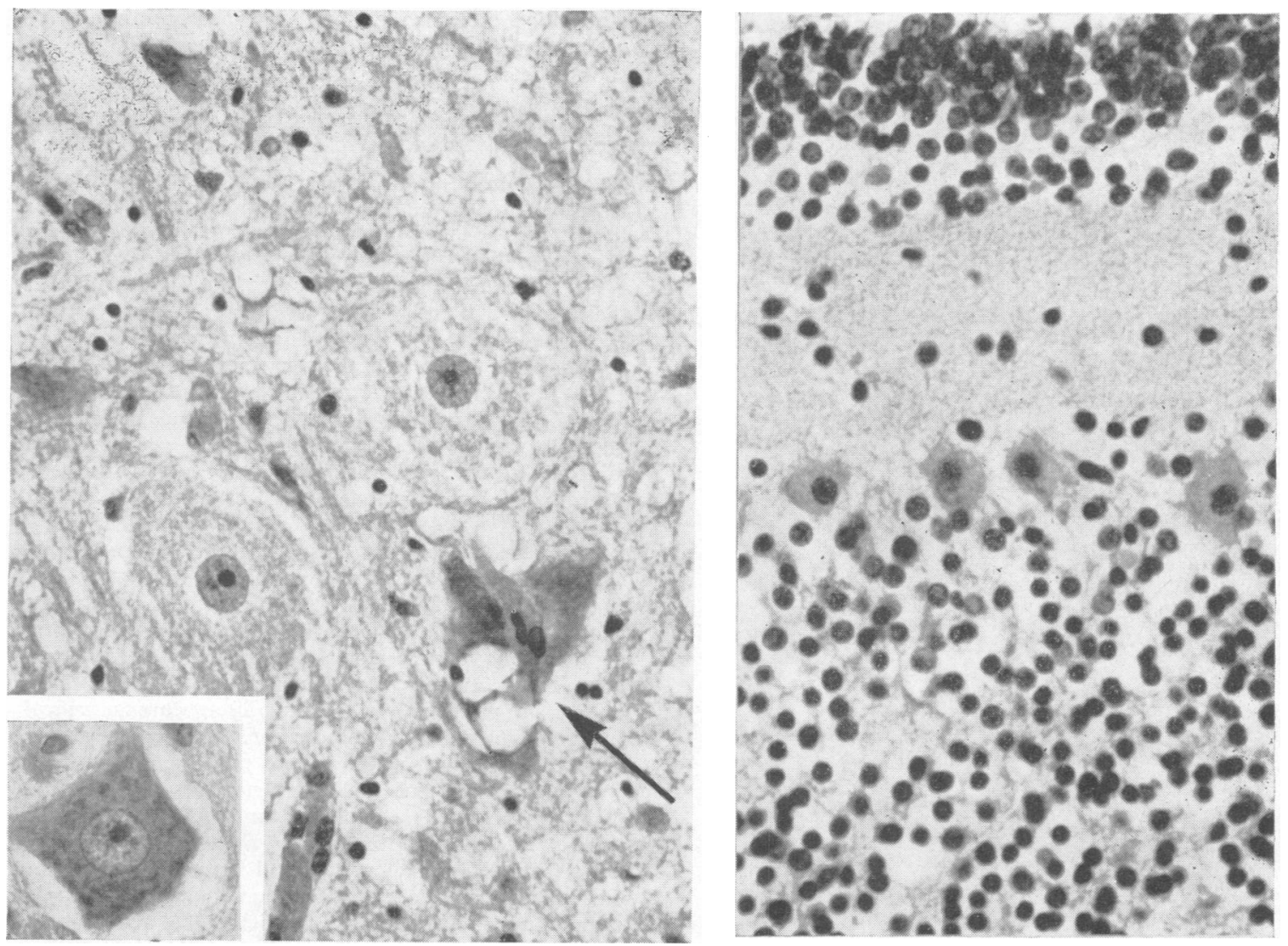

FIG. 6 .

FIG. 7.

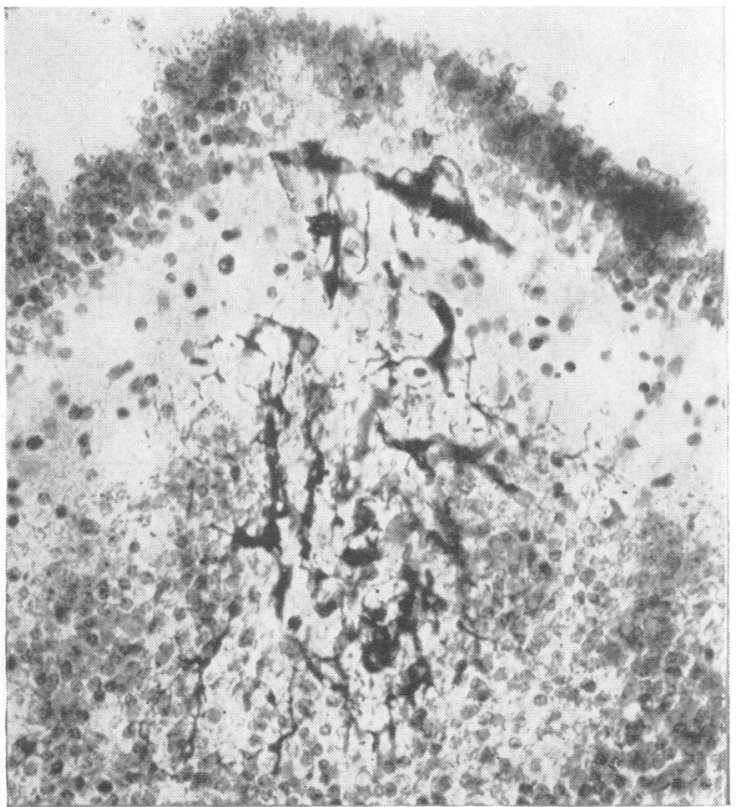

FIG. 6. Case 1. Anterior horn of spinal cord. The nuclei of motor neurones are small and dense and the cytoplasm is structureless and sometimes vacuolated (arrow). The glial nuclei are pyknotic. The inset shows a normal anterior horn cell from a baby of the same gestational age ( $H \& E$ $\times 480$ ).

FIG. 7. Case 1. Cerebellum. The Purkinje cells have shrunken and crenated nuclei and granular cytoplasm. Cells in the internal granular layer have pyknotic nuclei. The external granular layer (at the top) is normal in appearance $(H \& E \times 560)$.

FIG. 8. Case 1. A collection of microglial cells in the cerebellar cortex $($ Weil-Davenport $\times 275)$.

FIG. 8 . 


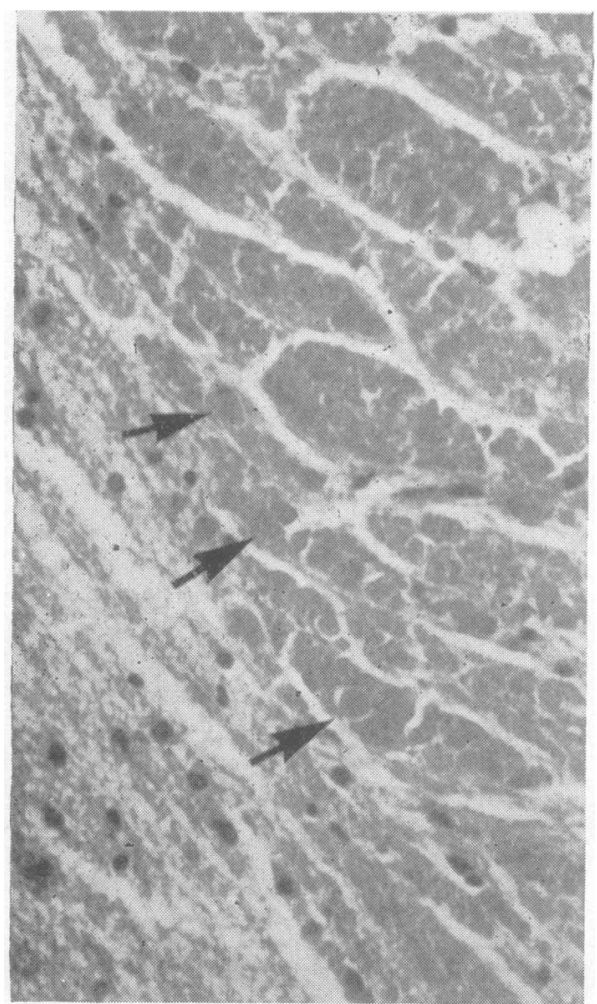

FIG. 9. Case 1. An area of leukomalacia near the temporal horn of the lateral ventricle. There is coagulation necrosis; the nerve fibres (arrows) are swollen and eosinophilic. There is no glial reaction at the margin of the focus ( $H \& E \times$ 420).

trigeminal nucleus (Fig. 5) and facial nucleus, the ventral nucleus of the lateral lemniscus, the inferior and superior olivary nuclei, the dorsal motor nucleus of the vagus, and the substantia nigra (Fig. 4). Only scattered abnormal neurones were present in other regions of the brainstem including the inferior colliculi and vestibular complex. In the cervical, thoracic, and lumbar spinal cord, nerve cells in all parts of the grey matter were degenerate, but anterior horn cells were particularly affected (Fig. 6).

A few nerve cells showed the appearance which has been called 'ischaemic cell change'. In this the cytoplasm is shrunken and intensely eosinophilic whilst the nucleus appears angular and densely pyknotic (Fig. 4a). Encrustation of nerve cells was not found.

Many normal looking glial nuclei were clearly discernible within the cortical ribbon, but in grey masses elsewhere nearly all glial nuclei were pyknotic. Reactive astrocytes were not seen, but a few small collections of microglial cells were present both in the cerebellum (Fig. 8) and in the cerebral cortex. In the globus pallidus and the anterior grey column of the spinal cord there was destruction of neutropil as well as of neurones and glial cells and the only normal looking nuclei were those of endothelial cells of blood vessels. The majority of the glial cells in the white matter in all parts of the brain showed acute degenerative change with pyknotic nuclei and eosinophilic cytoplasm. A few fragmented nuclei were present within the white matter. The myelin appeared normal but several small foci of leukomalacia were found close to the temporal horn of the lateral ventricles staining bright red with the periodic acid-Schiff technique. Nerve fibres of normal appearance could be stained in these foci but many were swollen and eosinophilic (Fig. 9). There was no marginal glial reaction.

Cells in the remnant of the paraventricular germinative zone and in the external granular layer of the cerebellum (Fig. 7) appeared to be unaltered. The ependyma and choroid plexus were normal in all areas examined. No abnormality was seen in posterior root ganglia, in peripheral nerves, or in muscles.

CASE 2 R. B., MALE (HAMMERSMITH HOSPITAL NO. 296478) Gestation 32 weeks. Birth weight $1,000 \mathrm{~g}$. (normal for this gestation 2,000-2,500 g.). This baby was born by spontaneous vertex vaginal delivery. He was the first child of a 22-year-old woman. He breathed immediately after birth, moved spontaneously and was of good colour, but was thin and scrawny, an appearance typical of severe intrauterine malnutrition. At 3 hours of age slight respiratory irregularity was noted and a catheter was inserted into the umbilical artery. During the first 40 hours repeated arterial $\mathrm{pO}_{2}$ and $\mathrm{pH}$ measurements were within normal limits. He was, however, awake most of the time, hyperactive and irritable, and despite frequent feeds, five out of seven blood glucose determinations during this period were below $20 \mathrm{mg} . / 100 \mathrm{ml}$. (Fig. 10). At 37 hours of age he vomited bile-stained

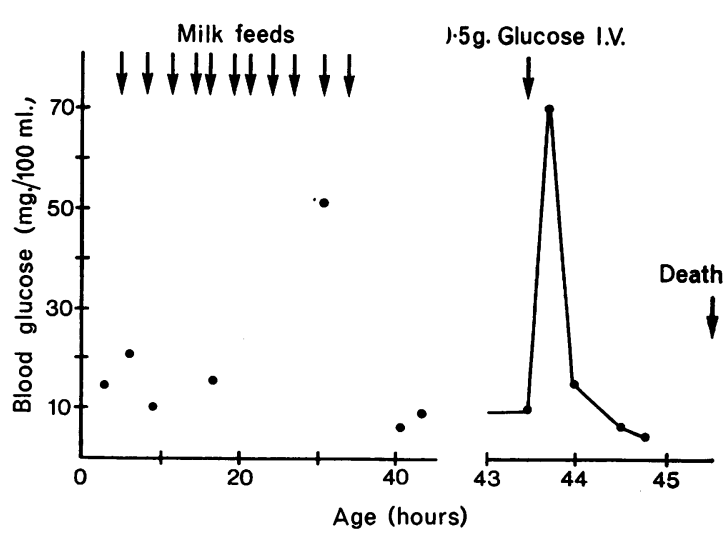

FIG. 10. Case 2. Blood glucose levels. The glucose tolerance test at $43 \frac{1}{2}$ hours of age shows an abnormally rapid disappearance rate of glucose $(K=13 \cdot 8)$.

fluid. At 41 hours of age he collapsed, became cyanosed and was very limp. He then began to have apnoeic attacks. These responded at first to manual stimulation 
and oxygen by face mask, but at 43 hours of age intermittent positive pressure respiration had to be started. Blood glucose was now $8 \mathrm{mg} . / 100 \mathrm{ml}$. and a glucose tolerance test was abnormal in that there was a very rapid disappearance of glucose $(K=13 \cdot 8)$. An electroencephalogram at 45 hours of age showed a flat record. At this time the arterial $\mathrm{pO}_{2}$ was $59 \mathrm{~mm}$. $\mathrm{Hg}$ and the arterial $p \mathrm{H}$ was 7.09 , the lowest values recorded. A slight improvement occurred after the intravenous glucose which had been given for the glucose tolerance test and also when $5 \mathrm{ml}$. trishydroxymethylaminomethane (THAM) was given intravenously, the $p \mathrm{H}$ rising to $7 \cdot 34$, but the baby's condition deteriorated again and he died aged 46 hours.

Pathological findings (Maudsley no. 3187) Necropsy was performed 72 hours after death. Thrombus was found in the abdominal aorta near the tip of the catheter and the inferior mesenteric artery was occluded. There was infarction of the descending and sigmoid colon with perforation and peritonitis. The liver was of normal appearance but weighed only 32 g. (normal $72 \pm 22$ g.). Subcutaneous fat was scanty. The thymus weighed 2 g. (normal $5 \cdot 5 \pm 2 \cdot 3$ g.). The lungs were atelectatic. The cardiovascular and genito-urinary systems, the endocrine glands, and spleen appeared macroscopically normal. The scalp, the skull, the meninges, and the venous sinuses were normal. The brain weighed $225 \mathrm{~g}$. (normal $234 \pm 41 \mathrm{~g}$.), giving a ratio of brain weight to liver weight of $7 \cdot 0$. Secondary sulci were well developed and tertiary sulci were visible; the lips of the Sylvian fissure were almost apposed. These features were in keeping with a gestational age of 32 weeks assessed from the menstrual history. On sectioning the brain, the white matter appeared congested but no other abnormality was seen.

Histology There was extensive oedema of the lungs. The descending colon showed recent infarction with a sanguinous peritoneal exudate. In the liver, the parenchymal cell cytoplasmic mass appeared to be reduced, and the sinusoids were large. Lymphocyte depletion was evident in the cortex of the thymus. No pathological features were found in the pancreas, kidneys, heart, or spleen.

Acute degeneration of neurones and glial cells was present throughout the central nervous system. The cytological features were similar to those in case 1 , although large nerve cells with intensely eosinophilic cytoplasm were more common in case 2 . The cerebal cortex (Fig. 11a) was severely involved, the occipital lobes being most affected, the temporal lobes least. A moderate number of abnormal nerve cells were present in the fascia dentata, the endfolium, and the pyramidal cell layer of the hippocampus. The caudate nucleus, putamen, globus pallidus, thalamus, and hypothalamus were severely involved. There was marked patchy loss of Purkinje cells both in the vermis and in the cerebellar hemispheres. The remaining Purkinje cells were eosinophilic and had pyknotic nuclei (Fig. 12a). The nuclei of cells of the internal granular layer and in neurones in the deep cerebellar nuclei were also pyknotic. Scattered abnormal nerve cells were seen in almost all the regions examined in the brainstem including the inferior colliculi. The oculomotor and trochlear nerve nuclei, the motor and principal sensory trigeminal nuclei and the superior and inferior olivary nuclei, however, were severely affected. As in case 1, the grey matter of the spinal cord showed severe degeneration; many anterior horn cells were scarcely recognizable and others showed striking cytoplasmic vacuolation (Fig. 13).

Many glial cells in the white and grey matter had pyknotic nuclei. Clusters of microglial cells were seen in the cerebellar cortex and white matter but not elsewhere in the brain.

The paraventricular germinative zone and the external

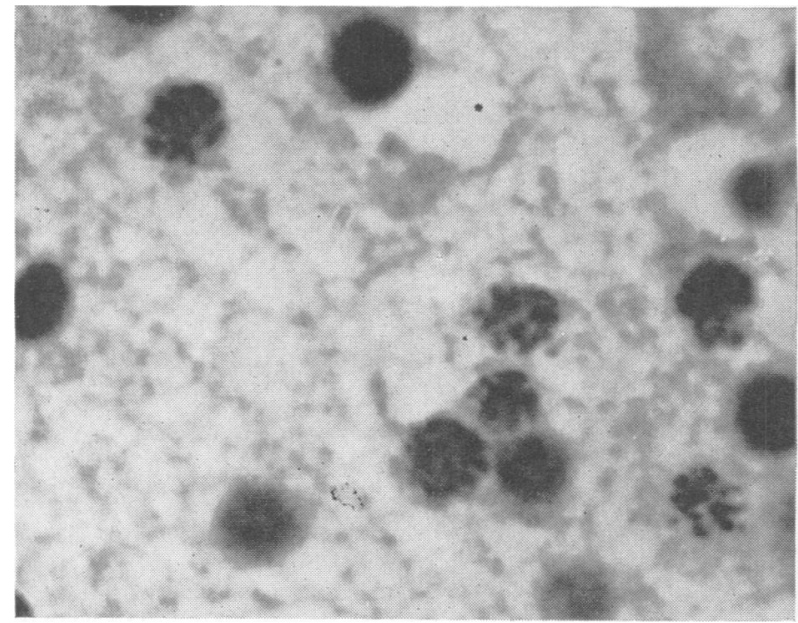

FIG $11 \mathrm{a}$.

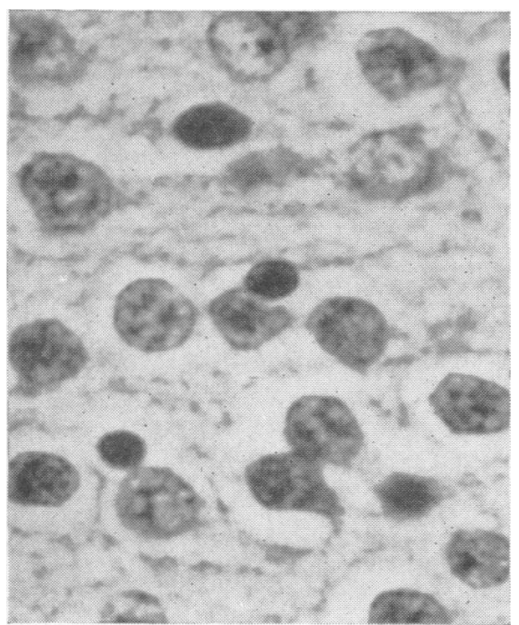

FIG. $11 \mathrm{~b}$.

FIG. 11a. Case 2. Insular cortex. Clumping of chromatin and fragmentation of nuclei are apparent. Compare with Fig. 116. $(H \& E \times 1,800)$.

FIG. 11b. Case 5. Treated hypoglycaemia. Normal looking nerve cells in insular cortex. Note the clearly defined nuclear membrane $(H \& E \times 1,200)$. 


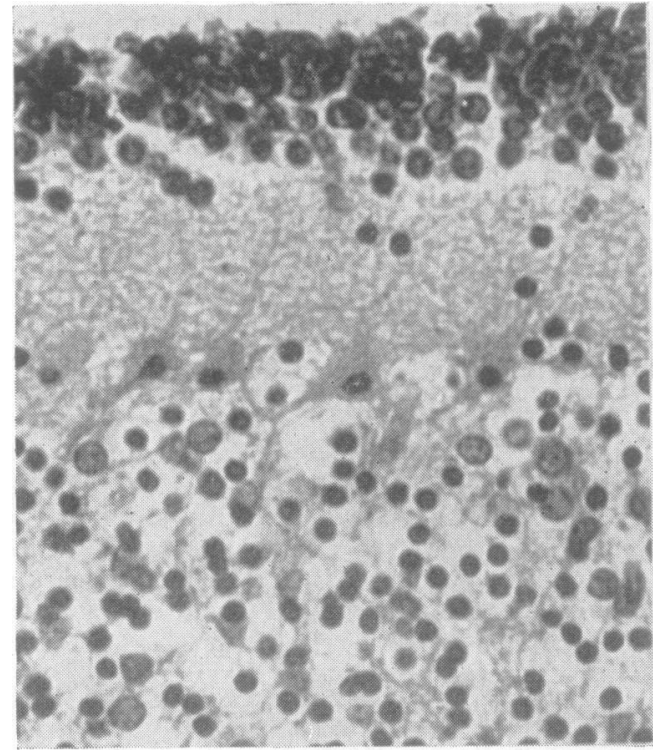

FIG. $12 \mathrm{a}$.

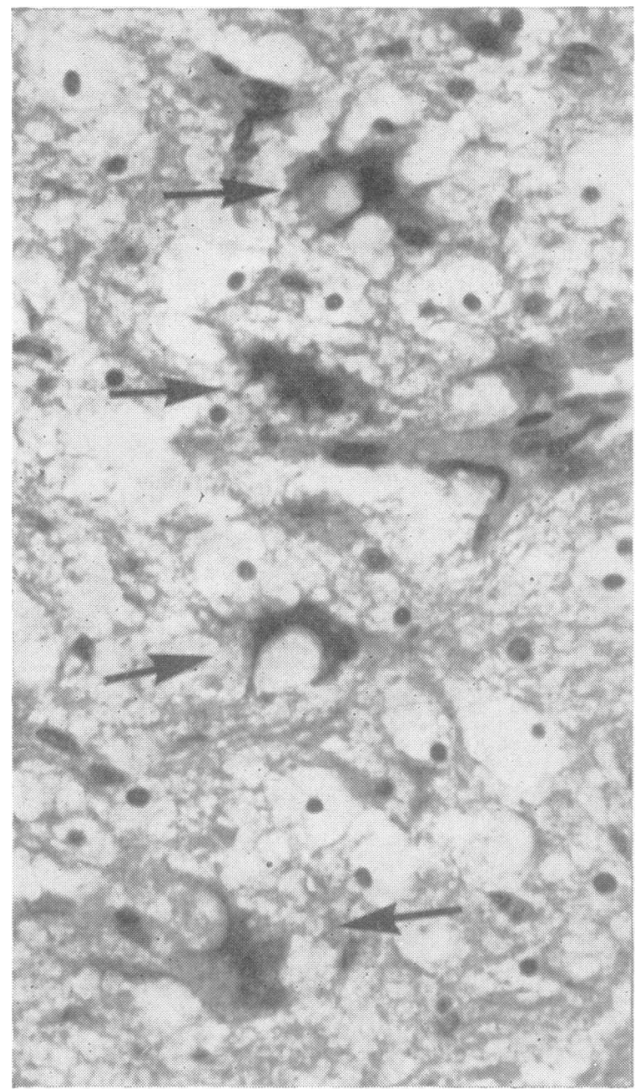

FIG. 13.

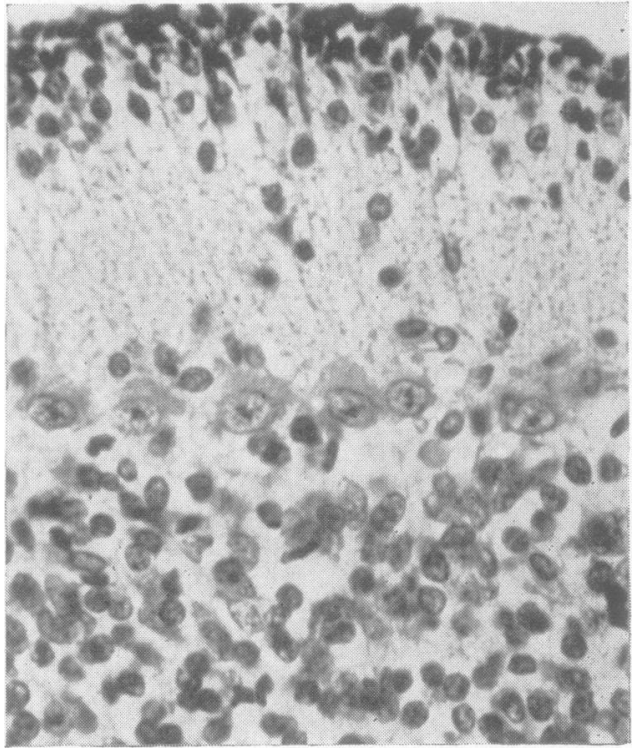

FIG. $12 b$.

FIG. 12a. Case 2. Cerebellum. The nuclei of Purkinje cells are pyknotic and the cytoplasm is intensely eosino- 0 philic. Many cells in the internal granular layer have densely pyknotic nuclei whilst those in the external granular layer are normal in appearance. Compare with Fig. $12 \mathrm{~b}$ $(H \& E \times 480)$.

FIG. 12b. Case 5. Cerebellum. The Purkinje cells and the external and internal granular layers of this treated case of hypoglycaemia appear normal $(H \& E \times 480)$.

FIG. 13. Case 2. Anterior horn of spinal cord. The architecture is disrupted. The remains of motor neurones (arrows) can be seen. Their cytoplasm contains large vacuoles $(H \& E \times 440)$. 
granular layer of the cerebellum appeared normal. The ependyma, the choroid plexus, posterior root ganglia, peripheral nerves, and muscles were normal in the sections examined.

CASE 3 H.D., FEMALE (HAMMERSMITH HOSPITAL NO. 260345) Gestation 28 weeks. Weight at death 1,050 g. (normal birth weight fort his gestational age 1,000-1,500 g.). This girl was the first child of a 21-year-old woman. Pregnancy had been normal until the spontaneous onset of premature labour. The baby was born by the breech and there was some difficulty in delivering the head. She needed resuscitation but by 5 minutes was breathing regularly. At 1 hour of age grunting and intercostal recession were noted but she remained pink with a normal respiratory rate in an ambient oxygen concentration of 28 to $40 \%$. At 7 hours of age respirations were normal but the baby was jittery. At 21 hours of age she began to have periods of apnoea which lasted 15 to 60 seconds and at first were easily stopped by handling and face mask oxygen. Later these episodes lasted up to five minutes, were accompanied by bradycardia, and became more difficult to abolish. Between the attacks the baby was not cyanosed but continued to be hyperactive and jittery. At 37 hours of age blood glucose was $36 \mathrm{mg}$. $/ 100 \mathrm{ml}$. She was given $2 \mathrm{ml}$. of $20 \%$ glucose orally at this time but otherwise was not fed. The periods of apnoea became more frequent and the baby became less responsive to endotracheal oxygen. Despite external cardiac massage she died aged 45 hours. Ten minutes after death the blood glucose was $3 \mathrm{mg} . / 100 \mathrm{ml}$. Samples of heart, skeletal muscle, liver, and lung were removed within 30 minutes of death for analysis of carbohydrate and lactate content. The values were found to be very low except in the lung where the tissue carbohydrate concentration was probably normal. (This infant is one of the series reported by Shelley (1964).)

Pathological findings (Maudsley no. 2016). Necropsy was carried out 15 hours after death. The lungs were atelectatic. Small recent haemorrhages were seen in the pleura, in the pericardium, and over the thymus. The liver appeared normal and weighed $40 \mathrm{~g}$. (normal $49 \pm 13$ g.). Other thoracic and abdominal organs were macroscopically normal. The brain weighed $140 \mathrm{~g}$. (normal $150 \pm 33 \mathrm{~g}$.), giving a ratio of brain weight to liver weight of 3.5 . Secondary sulci were present but there were no tertiary sulci and the island of Reil was exposed. These features were in keeping with a gestation of 28 weeks. On sectioning the brain extensive intraventricular haemorrhage was found. (This is a common finding in very premature babies and is not related to hypoglycaemia.)

Histology The lungs showed foci of haemorrhage and scattered collections of squamous epithelial cells in alveoli. Sinusoidal congestion was seen in the liver. No abnormality was recognized in the adrenal cortex, pancreas, kidneys, or spleen.

Degenerate nerve cells, showing the same features as in cases 1 and 2, were numerous in the cerebral cortex, especially in the occipital region (Fig. 14a) and in the putamen, the caudate nucleus, and the internal granular layer of the cerebellum. However, the number of nerve cells involved was not so great as in cases 1 and 2 and glial cells were not affected. The thalamus was patchily affected. Only a few abnormal neurones were found in the Purkinje cell layer, in the deep cerebellar nuclei and in the brainstem. In the thoracic and lumbar spinal cord, the anterior horn cells were markedly abnormal (Fig. 15a) showing pyknosis of the nuclei, chromatolysis, and cytoplasmic vacuolation. Motor cells in the cervical cord

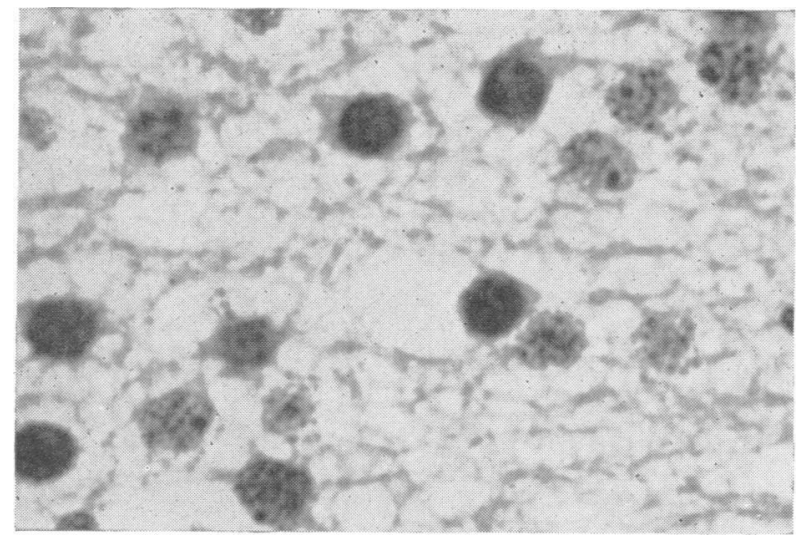

FIG. $14 a$

FIG. 14a. Case 3. Occipital cortex. The nuclei of some of the nerve cells are pyknotic, others show clumping of chromatin. The nuclear membrane is often indistinct. Compare with Fig. $14 \mathrm{~b}(H \& E \times 1,200)$.

FIG. 14b. Case 4. Treated hypoglycaemia. Occipital cortex showing normal looking nerve cells. The large nucleus is probably that of a glial cell $(H \& E \times 1,200)$.

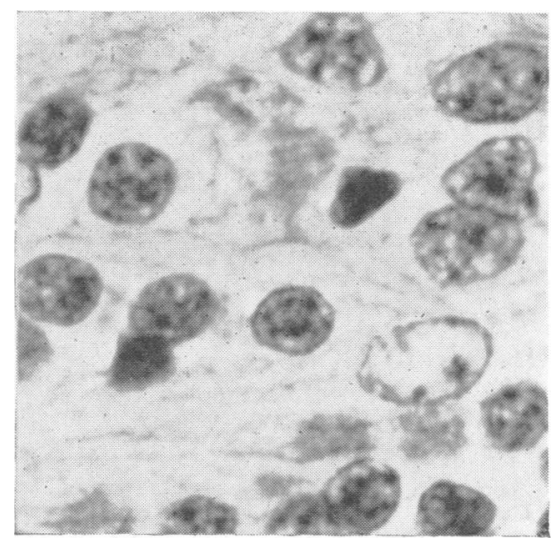

FIG. 14b. 
(Fig. 15b), in the oculomotor, trigeminal, and facial nuclei appeared normal. There was recent haemorrhage in the germinative zone near the terminal vein but cells in the germinal layer were normal. There was no proliferation of astrocytes or of microglial cells.

\section{TREATED PATIENTS}

CASE 4 R. L., MALE (HAMMERSMITH HOSPITAL NO. 303349) Gestation 25 weeks, birth weight $820 \mathrm{~g}$. (normal-no data available). This baby was the first child of a 31-year-old woman and was born by spontaneous vertex delivery. He did well for the first 48 hours although he needed an ambient oxygen concentration of 80 to $90 \%$ to maintain a normal $\mathrm{pO}_{2}$. At 11 hours of age blood glucose was $31 \mathrm{mg} . / 100 \mathrm{ml}$. He was fed 2-3 ml. of breast milk every three hours from the age of 12 hours, but despite this the blood glucose was found to be $11 \mathrm{mg} . / 100 \mathrm{ml}$. at 59 hours of age. After one and a half hours fast a glucose tolerance test was performed and showed an abnormally rapid disappearance of glucose from the blood $(K=2 \cdot 5)$. At 69 hours of age, two hours after a feed, blood glucose had again dropped to $12 \mathrm{mg} . / 100 \mathrm{ml}$. and an intravenous infusion of equal parts of $20 \%$ glucose and $40 \%$ fructose was given for one and a half hours. In the next 24 hours he had several apnoeic attacks. At 88 hours of age the blood glucose was $9 \mathrm{mg} . / 100 \mathrm{ml}$. and the intravenous infusion of hexoses was restarted. A normal blood glucose level was thus maintained until death. Nevertheless, the infant had further periods of apnoea of increasing length finally requiring almost constant intermittent positive pressure respiration. Arterial oxygen saturation was low and the arterial $p \mathrm{H}$ was less than 7.0 on many occasions in the next four days in spite of treatment with THAM. He died aged $7 \frac{1}{2}$ days.

Pathological findings (Maudsley no. 3487) At nec- ropsy the lungs were well aerated. The liver appeared normal and weighed $36 \mathrm{~g}$. The skull, the meninges, and the venous sinuses were normal. The brain weighed $96 \mathrm{~g}$. so that the ratio of brain weight to liver weight was 2.7. The convolutional development was in keeping with the stated gestational age of 25 to 26 weeks. Recentlyshed blood was present in the cerebellopontine cisterns, in the subarachnoid space over the parietal region of the right cerebral hemisphere, and over the spinal cord. On sectioning the brain, the entire ventricular system was found to be filled with blood clot.

Histology In the cortex of the thymus lymphocytes were reduced in number. The lungs, liver, adrenal glands, heart, and spleen appeared normal.

The cerebral cortex was normal (Fig. 14b) except that in the endfolium of each Ammon's horn there was a small number of nerve cells with shrunken and eosinophilic cytoplasm and irregular pyknotic nuclei. The same features were found in scattered neurones in the ventral part of the thalamus, in the hypothalamus, the globus pallidus and the dentate nucleus. In the brainstem a few affected nerve cells were seen in the inferior colliculi, the reticular formation, the griseum pontis, and the inferior olivary nuclei. There were no cells showing clumping of chromatin or karyorrhexis. Large motor neurones in brainstem and spinal cord were normal. Glial cells were unchanged throughout. Recent haemorrhage was seen in the paraventricular germinative zone.

Three additional abnormal features were present. In each hippocampal formation, cells very much like spongioblasts or neuroblasts were arranged in pallisade fashion immediately deep to the fascia dentata. In the cerebellar vermis, there were many gaps in the Purkinje cell layer both on the crests of gyri and within sulci. Some nerve cells in posterior root ganglia were smaller than normal and showed chromatolysis and eccentric nuclei.

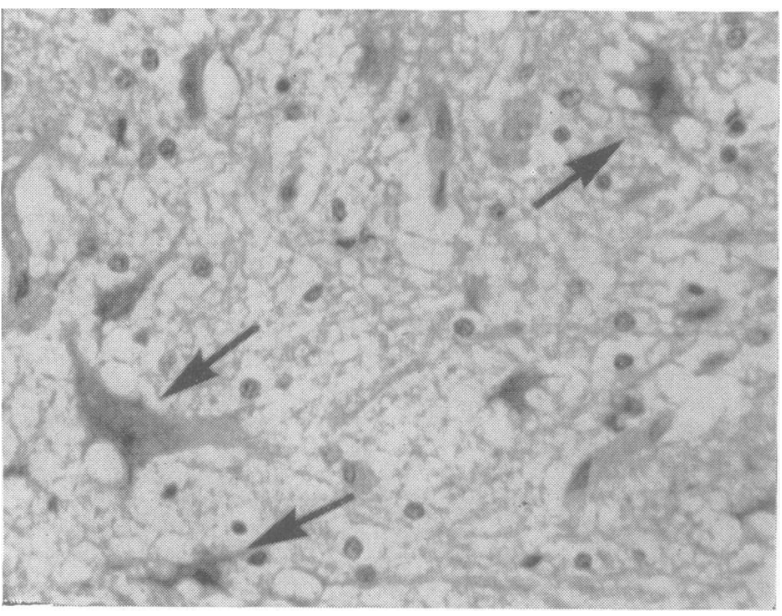

FIG. 15 a.

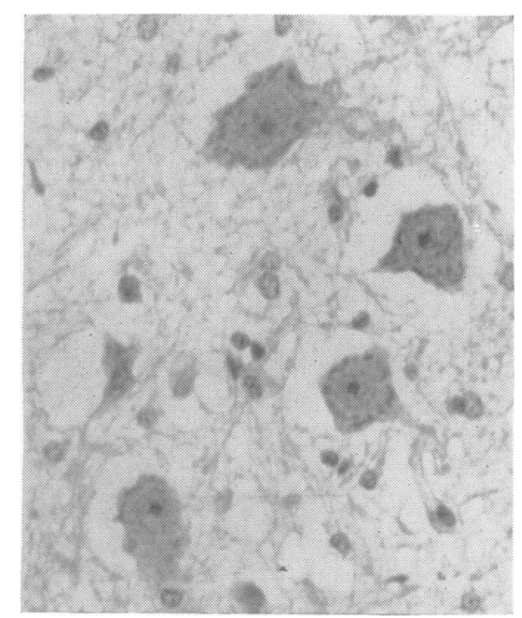

FIG. $15 \mathrm{~b}$.

FIG. 15. Case 3. Anterior horn of (a) the lumbar spinal cord and (b) the cervical spinal cord. Motor neurones (arrows) in the lumbar region are eosinophilic, shrunken and vacuolated. Anterior horn cells in the cervical region look normal $(H \& E \times 320)$. 
CASE 5 A. T., MALE (HAMMERSMITH hOSPITAL NO. 298298) This was the third child of a 25-year-old woman who had congenital heart disease (Fallot's tetralogy). He was born by elective Caesarean section under local anaesthesia. The gestational age, according to his mother's menstrual history, was 37 weeks, but the electroencephalogram, neurological examination, and anatomical features of the brain at necropsy suggested that maturity was 32-34 weeks. The birth weight was $1,160 \mathrm{~g}$. (normal for $32-34$ weeks is in the range of 2,000 to 2,500 g.). Soon after birth the infant was in good condition but he had evidently suffered intrauterine malnutrition for he was very small and thin and had a relatively large head. At 2 hours of age the blood glucose level was less than $10 \mathrm{mg} . / 100 \mathrm{ml}$. and in the first 11 hours of life this child's blood glucose was below $20 \mathrm{mg} . / 100 \mathrm{ml}$. except for one hour during a glucose tolerance test which was abnormal $(K=2 \cdot 1)$. Yet there were no symptoms attributable to hypoglycaemia. At 6 hours of age blood glucose was less than $10 \mathrm{mg} . / 100 \mathrm{ml}$. and $60 \mu \mathrm{g}$. of glucagon produced a rise to only $19 \mathrm{mg} . / 100 \mathrm{ml}$. one hour later. Hydrocortisone and glucagon were given and at 11 hours of age an intravenous infusion containing $7 \frac{1}{2} \%$ glucose and $32 \frac{1}{2} \%$ fructose was started; blood glucose levels remained within normal limits until death. At no time was there respiratory distress. A systolic murmur was heard at the age of 1 hour and was thought to be due to a ventricular septal defect. The baby collapsed and died aged 64 hours.

The mother's first pregnancy ended at 12 weeks. In the second pregnancy she gave birth at 37 weeks to a baby who weighed $1,420 \mathrm{~g}$. and died of hypoglycaemia aged 30 hours.

Pathological findings (Maudsley no. 3299) Necropsy was performed 52 hours after death. The left ventricle of the heart and the aortic arch were found to be hypoplastic and there was a coarctation of the aorta immediately proximal to the ductus arteriosus. A small defect, $2 \mathrm{~mm}$. in diameter, was present in the interventricular septum. The liver was normal in appearance but weighed only $36 \mathrm{~g}$. (normal $86 \pm 22 \mathrm{~g}$.). The thymus weighed less than $1 \mathrm{~g}$. Other thoracic and abdominal viscera appeared normal. The skull, the meninges, and the venous sinuses were normal. The brain weighed $234 \mathrm{~g}$. (normal for 33-34 weeks' gestation $275 \pm 39$ g.), giving a ratio of brain weight to liver weight of 6.5 . Tertiary sulci were well developed, corresponding with a gestational age of 32-34 weeks. There was no macroscopic abnormality in the brain either externally or on the cut surface.

Histology Considerable haemorrhage was found in the lungs, with masses of fibrin lying free in bronchioles, alveolar ducts, and some alveoli. The thymus showed lymphocyte depletion of the cortex. No abnormal features were seen in the adrenal glands, pancreas, liver, kidneys, or spleen.

The cerebral cortex (Fig. 11b) and white matter were normal in all areas examined. The caudate nucleus, claustrum, putamen, and globus pallidus were also normal, but a few neurones in the thalamus and hypothalamus showed irregular pyknotic nuclei and eosinophilic cytoplasm. The majority of the neurones in the dentate nucleus had the same appearance but the cerebellar cortex (Fig. 12b) was normal. In the brainstem scattered nerve cells in the substantia nigra, inferior colliculi, reticular formation, griseum pontis, and inferior olivary nucleus were shrunken and eosinophilic. The spinal cord, peripheral nerves, and muscles were normal.

CASE 6 E. J., MALE (HAMMERSMTth hospitAL NO. 299470) Gestation 38 weeks. Birth weight $1,400 \mathrm{~g}$. (normal $3,000-3,500$ g.). This baby was the second and smaller of undiagnosed uniovular twins. His mother was a multiparous negress aged 18 years. Pregnancy had been normal. The infant's condition at birth was good but he was small for his gestational age. At 16 hours of age jitteriness was noted. Blood glucose at this time was less than $10 \mathrm{mg} . / 100 \mathrm{ml}$. At 24 hours of age a glucose tolerance test was performed which showed a high disappearance rate of glucose $(K=1 \cdot 8)$. Treatment with glucagon and A.C.T.H. was begun. At 27 hours of age he was no longer jittery but the blood glucose level was still less than $10 \mathrm{mg} . / 100 \mathrm{ml}$. At 34 hours of age an intravenous infusion of equal parts of $10 \%$ glucose and $40 \%$ fructose was started and continued for 24 hours. After this blood glucose levels were measured frequently and were never below $40 \mathrm{mg} . / 100 \mathrm{ml}$. A.C.T.H. and glucagon were gradually discontinued after five days. From the third day on the baby appeared to be well but he was hyperactive and slightly hypertonic. At 8 weeks of age and again three weeks later his oxygen consumption was found to be unusually high. Serum protein-bound iodine was within normal limits $(3.7 \mu \mathrm{g}$./ $100 \mathrm{ml}$.). He was discharged aged 11 weeks, weighing $3,740 \mathrm{~g}$. and when seen in the clinic subsequently he was well and developing normally.

At the age of 6 months he was readmitted suffering from bronchopneumonia. The blood glucose level was recorded twice; values of 240 and $150 \mathrm{mg} . / 100 \mathrm{ml}$. were obtained. He developed heart failure and there were several episodes of cardiac arrest in one of which he died 48 hours after admission.

Pathological findings (Maudsley no. 3699) Necropsy was done 23 hours after death. The body was that of a well-nourished male negro child weighing 6,024 g. (normal mean $7.9 \mathrm{~kg}$.). Confluent bronchopneumonia was seen in both lungs. Other thoracic and abdominal viscera showed no abnormal features. The liver weighed 170 g. (normal $260 \pm 60$ g.) and the kidneys weighed $27 \mathrm{~g}$. each (normal $31 \pm 7 \mathrm{~g}$.). The adrenal glands were of normal size and together weighed $3.0 \mathrm{~g}$. The meninges and venous sinuses were normal. The brain weighed 600 g. (normal $760 \pm 70$ g.). There was no cortical atrophy or microgyria. No macroscopic abnormality was found on slicing the brain and the ventricles were of normal size.

Histology The presence of bronchopneumonia was confirmed. The adrenal cortex was generally of normal thickness but was irregularly nodular and there were multiple rounded nodules of cortical cells external to the capsule. The adrenal medulla appeared normal, as did the thyroid gland.

No pathological features were seen in the central nervous system. There was no focal or laminar cell loss 
in the cerebral cortex, including Ammon's horn, but it should be pointed out that slight or even moderate diffuse cell loss cannot be detected with routine histological methods. Astrocytes and microglia were normal in number. There was no fibrous gliosis. The caudate nucleus, putamen, claustrum, globus pallidus, thalamus, and cerebellum were normal in all respects. No abnormality was found in the midbrain, pons, medulla or in cervical, thoracic and lumbar spinal cord.

\section{DISCUSSION}

The clinical and biochemical findings in our six cases strongly suggest that all the infants suffered from prolonged hypoglycaemia in the first few days after birth. Salient clinical features are summarized in the Table. Degeneration in the nervous system was found in the three untreated cases only. In the three cases in which the hypoglycaemic state was corrected the brain was almost entirely normal histologically, suggesting that treatment had been effective in preventing brain damage.

Severe hypoglycaemia can be suspected in the newborn on clinical grounds but the signs are not specific and the diagnosis has to be confirmed by biochemical investigation, or by obtaining a prompt response to intravenous glucose. Four of the present cases had some of the signs usually associated with hypoglycaemia. Such signs include irritability and wakefulness, jitteriness (irregular oscillations of the limbs occurring about 10 times a second), and an abnormal Moro response. If hypoglycaemia is prolonged the baby may become lethargic, limp, and pale. There may be periods of apnoea (cases 2 and 3) or convulsions (case 1). It should be emphasized that none of these signs is peculiar to hypoglycaemia. A blood glucose level below $20 \mathrm{mg} . / 100 \mathrm{ml}$. was recorded during life in cases $1,2,4,5$, and 6 and in case 3 biochemical estimations done after death on blood and tissues strongly suggested that hypoglycaemia had been present. In four of the infants a deranged carbohydrate metabolism was confirmed by an intravenous glucose tolerance test (Fig. 10) which showed an abnormally rapid disappearance of glucose from the blood indicating that tissue demand for glucose outstripped the supply.

The blood glucose concentration normally falls immediately after birth and this fall is greater in premature babies (Cornblath and Reisner, 1965) and those who are underweight for their gestational age (Neligan, Robson, and Watson, 1963). Isolated blood glucose readings below $20 \mathrm{mg}$. $/ 100 \mathrm{ml}$. are occasionally observed in apparently well babies (Haworth and Ford, 1960) and it is clearly of importance to distinguish such transient hypoglycaemia, which apparently produces no ill effects, from hypoglycaemia lasting many hours which gives rise to symptoms and may eventually lead to irreversible brain damage or to death. Infants of diabetic women may also become temporarily hypoglycaemic within the first 48 hours of birth because of an oversensitive insulin release mechanism (Baird and Farquhar, 1962) and this occasionally gives rise to symptoms (Komrower, 1954) but permanent neurological abnormalities have not been reported in such children.

In the first day of life before feeding is established, glycogenolysis in the liver is the main source of circulating glucose and a deficiency of liver carbohydrate stores is probably the most common cause of severe neonatal hypoglycaemia (Shelley and Neligan, 1966). It is important to appreciate which babies are likely to have poor carbohydrate reserves so that the diagnosis can be considered and treatment begun before symptoms develop. At birth the liver carbohydrate content per unit weight is about twice that of the adult and most of this is laid down in the last three months of foetal life (Shelley, 1964). Very premature babies are therefore apt to become hypoglycaemic even if feeding is not delayed and our cases 3 and 4 are examples of this.

The other group of infants with low carbohydrate stores are those that have suffered from intrauterine

TABLE

SUMMARY OF CLINICAL AND PATHOLOGICAL FINDINGS

\begin{tabular}{|c|c|c|c|c|c|c|c|c|c|}
\hline \multirow[t]{2}{*}{ Case } & \multirow[t]{2}{*}{$\operatorname{Sex}$} & \multirow{2}{*}{$\begin{array}{l}\text { Gestation } \\
\text { (weeks) }\end{array}$} & \multirow{2}{*}{$\begin{array}{l}\text { Age at } \\
\text { Death }\end{array}$} & \multirow{2}{*}{$\begin{array}{l}\text { First } \\
\text { Symptoms } \\
\text { at }\end{array}$} & \multirow{2}{*}{$\begin{array}{l}\text { Approximate } \\
\text { Duration of } \\
\text { Hypoglycaemia }\end{array}$} & \multirow[t]{2}{*}{ Other Features } & \multirow{2}{*}{$\begin{array}{l}\text { Brain Weight/ } \\
\text { Liver Weight } \\
\text { Ratio }^{1}\end{array}$} & \multicolumn{2}{|l|}{ Brain Damage } \\
\hline & & & & & & & & Macroscopic & Microscopic \\
\hline $\begin{array}{l}1 \\
2 \\
3 \\
4\end{array}$ & $\begin{array}{l}\mathbf{M} \\
\mathbf{M} \\
\mathbf{F} \\
\mathbf{M}\end{array}$ & $\begin{array}{l}39 \\
32 \\
28 \\
25\end{array}$ & $\begin{array}{l}55 \frac{1}{2} h r . \\
45 \frac{1}{2} \mathrm{hr} . \\
45 \frac{1}{2} \mathrm{hr} . \\
7 \frac{1}{2} \text { days }\end{array}$ & $\begin{array}{l}17 \mathrm{hr} . \\
3 \mathrm{hr} . \\
7 \mathrm{hr} . \\
\text { None }\end{array}$ & $\begin{array}{l}38 \mathrm{hr} . \\
40 \mathrm{hr} . \\
38 \mathrm{hr} . \\
37 \mathrm{hr} \text {. inter- } \\
\text { mittent }\end{array}$ & $\begin{array}{l}\text { Malnourished, convulsions } \\
\text { Malnourished, peritonitis } \\
\text { Apnoeic episodes } \\
\text { Hypoxic }\end{array}$ & $\begin{array}{l}4 \cdot 4 \\
7 \cdot 0 \\
3 \cdot 5 \\
2 \cdot 7\end{array}$ & $\begin{array}{l}\text { Normal } \\
\text { Normal } \\
\text { i.v.h. } \\
\text { i.v.h. }\end{array}$ & $\begin{array}{r}++++ \\
++++ \\
++ \\
+\end{array}$ \\
\hline 5 & $\mathbf{M}$ & 33 & $64 \mathrm{hr}$. & None & $9 \mathrm{hr}$. & $\begin{array}{l}\text { Malnourished, malformed } \\
\text { heart }\end{array}$ & $6 \cdot 8$ & Normal & + \\
\hline $\begin{array}{l}6 \\
\text { i.v.h }\end{array}$ & $\mathbf{M}$ & tricular & $6 \mathrm{mth}$. & $\begin{array}{l}16 \mathrm{hr} . \\
{ }^{1} \text { norma }\end{array}$ & $\begin{array}{l}18 \mathrm{hr} \text {. inter- } \\
\text { mittent } \\
1 \text { less than } 3\end{array}$ & $\begin{array}{l}\text { Malnourished smaller twin } \\
++++=\text { very severe; }\end{array}$ & $\begin{array}{c}- \\
++=\text { severe }\end{array}$ & $\begin{array}{l}\text { Normal } \\
\qquad+=\text { slight; }\end{array}$ & $\mathrm{O}=$ none \\
\hline
\end{tabular}


malnutrition and are therefore small for their gestational age. About $5 \%$ of babies are so affected (Butler and Bonham, 1963). Many of the organs in these so-called 'small for dates' infants weigh less than normal (Gruenwald, 1963) while the brain is much less affected by the general growth retardation. The liver of malnourished infants is particularly small and, furthermore, contains less carbohydrate per unit weight than normal (Shelley, 1964). It is thus unable to supply enough glucose for the relatively large brain. Quantitative histological studies of the liver in underweight babies have shown that the cytoplasmic mass of the parenchymal cells is reduced (Naeye, 1964). This is partly due to lack of glycogen, and partly due to lack of protein and therefore possibly of enzymes. Consequently, gluconeogenesis in the liver may be impaired. The mass of the adrenal cortex and particularly of the foetal zone, is also smaller than normal in malnourished babies (Naeye, 1965). Since adrenal corticoids promote gluconeogenesis, relative adrenal cortical insufficiency may be another factor in the inability of the underweight infant to maintain blood glucose levels. Brown and Wallis (1963) found a normal urinary excretion of 17 -ketosteroids and 17-ketogenic steroids in three malnourished babies, but there have been no observations on the levels of circulating corticosteroids in such infants.

The clinical recognition of a 'small for dates' baby is not always easy. In our case 1 , for example, the birth weight was within normal limits, yet the ratio of brain weight to liver weight when established after death was 4.4 (the normal ratio (Dawkins, 1964) is less than 3), indicating that this infant was malnourished. Because this was not recognized, hypoglycaemia was not at first considered as a possible cause for his symptoms. The cause of the intrauterine growth retardation is not known in cases 1 and 2 . In case 5 the mother suffered from severe cyanotic congenital heart disease which may have led to placental insufficiency. Case 6 was the smaller of twins; being 'small for dates', such infants are prone to develop hypoglycaemia (Reisner, Forbes, and Cornblath, 1965).

Cornblath and Reisner (1965) have listed the rarer causes of prolonged neonatal hypoglycaemia, which include hereditary metabolic abnormalities such as glycogen storage disease, hereditary fructose intolerance, galactosaemia, and leucine intolerance, the last of which gives rise to hyperinsulinism. Children with 'spontaneous idiopathic hypoglycaemia' (McQuarrie, 1954; Hartmann and Jaudon, 1937; Broberger and Zetterström, 1961) may have their first hypoglycaemic attack in the neonatal period. It has been suggested by various workers (Hartmann and Jaudon, 1937; Cornblath et al.,
1964; Haworth and McRae, 1965) that disease or malformation of the central nervous system was a cause of neonatal hypoglycaemia in some of their cases but the evidence cited is quite unconvincing.

Striking abnormalities were seen in the nerve cells of the three untreated cases. In small nerve cells (Figs. 1a, 2, 11a and 14a) the nuclear membrane was indistinct or absent and there was clumping of chromatin. In many cells the nucleus had broken up into numerous small uniform fragments which were scattered in the cytoplasm; in others the chromatin had formed a beaded pyknotic mass. In large nerve cells (Figs. 3a, 4a, 5 and 6) the nuclei were shrunken, opaque and finely stippled and there was chromatolysis. Many of the motor neurones of the cranial nerve nuclei and of the spinal cord were disrupted by large vacuoles (Figs. 13 and 15a). The nuclei of the glial cells both in the grey and white matter were pyknotic in cases 1 and 2 . These cytological reactions in large and small nerve cells are not peculiar to hypoglycaemia for we have seen them in infants dying with severe hypoxia. Somewhat similar changes have been described in nerve cells in adult hypoglycaemia (Lawrence et al., 1942). The classical 'ischaemic nerve cell change', in which the cytoplasm is eosinophilic and the nucleus irregular and pyknotic, occurs only rarely in neonatal hypoglycaemia (Fig. 4a) though it is frequently seen in babies who have been hypoxic. A few 'ischaemic' nerve cells were seen in case 4 who was hypoxic and acidaemic for three days after correction of the hypoglycaemia and also in case 5 who died of congenital heart disease after the hypoglycaemia had been successfully treated. Neither fragmented nuclei nor chromatolysis was seen in these two cases and the histological abnormalities in the brain were slight compared to those seen in the three cases with untreated hypoglycaemia.

None of the cytological abnormalities seen in the brains of our patients can be attributed to ordinary post-mortem autolysis. In case 1 necropsy was carried out nine hours after death and histology of the other organs in this and the other cases showed no unusual degree of post-mortem change. Furthermore, sections taken from the brains of infants not in this series, on whom necropsy has been delayed for as long as three to four days, show none of the changes described above in the anterior horn cells or other large or small nerve cells. Nevertheless, it seems unlikely that all of the changes seen in the brainstem and spinal cord in our three cases occurred during life since the first patient at least was breathing spontaneously until he died. Disrupted and vacuolated ventral horn cells very similar to those described here were also seen by Winkelman and Moore 
(1940) in cats killed immediately after hypoglycaemic convulsions and it seems possible that nerve cells dying in a hypoglycaemic state undergo particularly rapid and sudden dissolution.

In patients 1 and 2, who died with untreated hypoglycaemia, severe degeneration was seen in the nerve cells and glial cells throughout the central nervous system. Only the germinative zones showed no histological abnormalities, and this is in keeping with the findings of Hicks (1953) who showed that in the developing nervous system of rats and mice the germinative areas were resistant to hypoglycaemia. In case 3 the changes were not so severe. They were most marked in the putamen, the caudate nucleus, and in the internal granular layer of the cerebellum. The cerebral cortex and thalamus were also involved but less so than in cases 1 and 2 . The lower brainstem and the dentate nucleus were almost normal and the cervical spinal cord was spared, though the thoracic and lumbar segments were severely affected. In all three cases the cerebral cortex in the occipital region and in the insula was more severely affected than that in the frontal region. The temporal lobes were least affected, though a few abnormal cells were present in all layers of the hippocampus. No cortical layer was selectively involved and the cortex at the bottom of sulci was not especially affected. The cortex at the boundary zones between the territories of the major cerebral arteries (watershed regions) was not more severely involved than that elsewhere.

The distribution of grey matter lesions in neonatal hypoglycaemia is thus in striking contrast to that found in brain damage due to various forms of hypoxia and ischaemia, in which certain areas are selectively involved both in the adult human (Meyer, 1963; Adams, Brierley, Connor, and Treip, 1966) and in the newborn experimental animal. In experimentally asphyxiated foetal rhesus monkeys (Ranck and Windle, 1959; Jacobson and Windle, 1960) the inferior colliculi and certain other brainstem nuclei and parts of the basal ganglia are frequently and severely involved, whereas the cerebral cortex is rarely affected. In older children with cerebral palsy various brain lesions such as focal or laminar cortical necrosis, lesions in arterial boundary zones, status marmoratus or cystic degeneration in the white matter have been described and have been attributed to 'perinatal anoxia' or 'birth trauma' (Malamud, 1963; Norman, 1963), but the acute lesions following hypoxia in the human newborn are poorly documented. Banker and Larroche(1962)reported slight changes, including nerve cells with karyorrhectic nuclei, in the cerebral cortex at the bottom of sulci, in the hippocampus, the pontine nuclei, and the Purkinje cell layer of the cerebellum. The more important lesions in their cases were small infarcts in the periventricular white matter which are well known to occur in babies and which Banker and Larroche related to hypoxia and to vascular disturbances involving the border zones of cerebral artery territories. Incidentally, two of their 51 cases suffered from neonatal hypoglycaemia. Areas of periventricular leukomalacia were seen in our case 1 and were the only circumscribed lesions found in our series.

That the brain damage following hypoglycaemia in the first week of life is so much more diffuse, severe and widespread than that following anoxia may be related to the way these two conditions affect the heart. Heart muscle not only has a better glycogen store than the brain (Shelley, 1964) but it is known to be able to utilize many exogenous substrates other than glucose for its energy supply. The heart may therefore not be susceptible to hypoglycaemia whereas it is at least as dependent on oxygen as is the brain. This may mean that babies who are severely hypoxic some time after birth die because the heart fails before extreme brain damage has had time to occur. Furthermore, focal lesions due to circulatory failure may be found superimposed on generalized hypoxic brain damage but are less likely to be encountered in hypoglycaemic brain damage. (The situation may be different during and immediately after birth. At this time heart muscle has a particularly high glycogen content which it can utilize in anaerobic glycolysis making it relatively resistant to anoxia (Mott, 1961).

The pattern of brain damage due to hypoglycaemia in adults (Lawrence et al., 1942) has certain similarities to that found in the newborn in that the cerebral cortex (mainly its outer layer) and the putamen and caudate nucleus are particularly severely affected. The brainstem, however, is relatively spared. The spinal cord, which was so strikingly involved in our babies, has only rarely been examined in the adult. Abnormal anterior horn cells have been reprrted in patients dying from hypoglycaemia (Moersch and Kernohan, 1938) and there are cases on record in which weakness of skeletal muscles and loss of anterior horn cells developed after episodes of severe hypoglycaemia usually due to islet cell adenoma of the pancreas (Lidz, Miller, Padget, and Stedem, 1949; Tom and Richardson, 1951; Bataille and Brucher, 1962). Pathological changes in the nervous system have also been seen in experimental animals made hypoglycaemic with insulin. Stief and Tokay (1932, 1935), using dogs and rabbits, found focal lesions which they attributed to vascular disturbances. Subsequent investigators, however, obtained diffuse neuronal degeneration in all parts of the 
nervous system (Weil, Liebert, and Heilbrunn, 1938; Winkelman and Moore, 1940). They also showed that the lesions they described were not due to the convulsions from which the animals suffered.

Although severe hypoglycaemia ultimately produces pathological changes in the brain, nervous tissue can survive a very low blood glucose level for remarkably long periods. Patients 4-6, who were successfully treated and whose nervous system was essentially normal histologically, had had blood glucose levels well below $20 \mathrm{mg}$. $/ 100 \mathrm{ml}$. for some nine hours, and cases 4 and 5 never even showed abnormal clinical signs. It is interesting that cases 1 and 2 only succumbed after hypoglycaemia had been present for some 36 hours.

It is currently thought that blood glucose is the only exogenous source of energy for the brain (McIlwain, 1966), but the question whether the nervous system can utilize other exogenous substrates may have to be reconsidered. The administration of lactate (Wortis, Bowman, Goldfarb, Fazekas, and Himwich, 1941) or of pyruvate (Goldfarb and Wortis, 1941) does not bring adults out of hypoglycaemic coma. There is some evidence, however, that lactate may act as fuel for the young brain, for it has been shown that insulin-induced hypoglycaemia in newborn calves does not lead to convulsions if the blood lactate level is high (Edwards 1964), and Scopes (1964) reported two infants with neonatal hypoglycaemia in whom symptoms did not appear until blood lactate had fallen to low levels.

Brain tissue does, of course, oxidize endogenous substrates other than glucose, e.g., amino acids and lipids. Under normal conditions the glucose molecule contributes carbon atoms to the synthesis of these substrates (Geiger, Horvath, and Kawakita, 1960; Barkulis, Geiger, Kawakita, and Aguilar, 1960; Vrba, 1962). Oxidation continues in the absence of glucose but resynthesis of the endogenous substrates is not possible and there is thus loss of tissue constituents. Geiger, Magnes, and Geiger (1952) found that when the intact brain of the cat is perfused with glucose-free 'simplified' blood there is only a slight reduction in oxygen consumption and brain function, as judged by the electroencephalogram, the presence of a corneal reflex, etc., is maintained for up to two hours. During this time there is a great reduction of protein, microsomes, phospholipids, and nucleotides (Abood and Geiger, 1955) and the respiratory quotient drops to less than 1.0. Further it has been shown (Barbato and Barbato, 1965) that the ribonucleic acid content of Purkinje cells is much reduced after insulin-induced hypoglycaemia in rats. The oxidation of cell components whick sannot be replaced in the absence of glucose is likely eventually to lead to irreversible damage to nerve cells and glial cells. The length of time for which cell changes remain reversible is not known.

Untreated hypoglycaemia carries a high mortality. In babies who have been inadequately treated but who survive, the most common sequelae are mental retardation, retarded motor development with or without spasticity, and microcephaly (Brown and Wallis, 1963; Cornblath et al., 1964; Haworth and McRae, 1965), suggesting that the cerebral cortex is particularly vulnerable to hypoglycaemia. Our cases 1 and 2 showed no evidence of selective involvement of any part of the central nervous system, but in case 3 the cerebral cortex, the caudate nucleus, and the putamen were more severely involved than the brainstem. Further detailed clinical and pathological studies are necessary before the relative resistance to hypoglycaemia of various nerve cell masses can be discussed.

The incidence of serious hypoglycaemia in the neonatal period is difficult to determine but it is probably 2 to 3 per 1,000 live births. For comparison, the incidence of Down's syndrome is 1 in 700 live births (Penrose, 1961). The largest group of infants at risk from hypoglycaemia consists of those that are underweight for their gestational age, that is approximately 20 per 1,000 full-term or 50 per 1,000 of all births. About $4 \%$ of these malnourished infants are likely to develop hypoglycaemia severe enough to produce symptoms and to require treatment (Davis, 1966).

The case histories and the pathological findings in the six infants here presented show that hypoglycaemia in the neonatal period can cause extensive lesions in the central nervous system and that such lesions can be prevented by vigorous treatment.

SUMMARY

The case histories and necropsy findings of six infants who suffered from prolonged hypoglycaemia in the first week of life are presented.

In three infants the hypoglycaemia was not treated: there was extensive degeneration of nerve cells throughout the central nervous system. In two of these cases glial cells were also affected.

In three cases the hypoglycaemia was corrected but the infants died from other causes later: only slight abnormalities were found in the brain.

The cytological features and the distribution of the nerve cell changes associated with neonatal hypoglycaemia are described. The causes and incidence of neonatal hypoglycaemia and the pathogenesis of the brain lesions are discussed.

It is concluded that hypoglycaemia in the first 
week of life is an important cause of brain damage which can be prevented by timely treatment.

We wish to thank Professor P. M. Daniel and Professor J. P. M. Tizard for their interest and encouragement. We are grateful to Mr. A. R. Salliss and his staff for technical assistance and to Mr. P. M. Taylor for the photographs. The necropsies on the six cases here presented were performed by the late Dr. M. J. R. Dawkins.

J. M. A. is in receipt of a grant from the Nuffield Foundation which has also provided for the expenses of this work. The biochemical work was made possible by a grant from the Sir William Coxen Trust.

\section{REFERENCES}

Abood, L. G., and Geiger, A. (1955). Breakdown of proteins and lipids during glucose-free perfusion of the cat's brain. Amer. J. Physiol., 182, 557-560.

Adams, J. H., Brierley, J. B., Connor, R. C. R., and Treip, C. S. (1966). The effects of systemic hypotension upon the human brain. Brain, 89, 235-268.

Anderson, J. M., Milner, R. D. G., and Strich, S. J. (1966). Pathological changes in the nervous system in severe neonatal hypoglycaemia. Lancet, 2, 372-375.

Baird, J. D., and Farquhar, J. W. (1962). Insulin-secreting capacity in newborn infants of normal and diabetic women. Ibid., 1, 71-74.

Banker, B. Q., and Larroche, J. C. (1962). Periventricular leukomalacia of infancy. Arch. Neurol. (Chic.) 7, 386-410.

Barbato, I. W. M., and Barbato, L. (1965). The effect of hypoglycaemia and insulin coma on the total R.N.A. content of isolated Purkinje cells. J. Neurochem., 12, 60-61.

Barkulis, S. S., Geiger, A., Kawakita, Y., and Aguilar, V. (1960). A study of the incorporation of ${ }^{14} \mathrm{C}$. derived from glucose into the free amino acids of the brain cortex. Ibid., 5, 339-348.

Bataille, J-P., and Brucher, J-M. (1962). Lésions cérébrales par hypoglycémie dans un cas de coma post-hypoglycémique mortel chez un diabètique traité depuis 34 ans. Diabète (Le Raincy), 10, 247-253.

Broberger, O., and Zetterström, R. (1961). Hypoglycemia with an inability to increase the epinephrine secretion in insulin-induced hypoglycemia. J. Pediat., 59, 215-222.

Brown, R. J. K., and Wallis, P. G. (1963). Hypoglycaemia in the newborn infant. Lancet, 1, 1278-1282.

Butler, N. R., and Bonham, D. G. (1963). Perinatal Mortality. Livirgstone, Edinburgh.

Cornblath, M., Odell, G. B., and Levin, E. Y. (1959). Symptomatic neonatal hypcglycemia associated with toxemia of pregnancy. J. Pediat., 55, 545-562.

_ matic neonatal hypoglycemia. Pediatrics, 33, 388-402.

_- , and Reisner, S. H. (1965). Blood glucose in the neonate and its clinical significance. New Engl. J. Med., 273, 378-381.

Davis, J. A. (1966). Personal communication.

Dawkins, M. J. R. (1964). In Discussion. Proc. roy. Soc. Med., 57, 1063-1064.

Edwards, A. V. (1964). Resistance to hypoglycaemia in the new-born calf. J. Physiol. (Lond.), 171, 46-47P.

Gallyas, F. (1963). Silver impregnation method for microglia. Acta neuropath. (Berl.), 3, 206-209.

Geiger, A., Magnes, J., and Geiger, R. S. (1952). Survival of the perfused cat's brain in the absence of glucose. Nature (Lond.) 170, 754-755.

-_, Horvath, N., and Kawakita, Y. (1960). The incorporation of 1 C. derived from glucose into the proteins of the brain cortex, at rest and during activity. J. Neurochem., 5, 311-322.

Goldfarb, W., and Wortis, J. (1941). Availability of sodium pyruvate for human brain oxidations. Proc. Soc. exp. Biol. (N.Y.), 46, 121-123.

Gruenwald, P. (1963). Chronic fetal distress and placental insufficiency. Biol. Neonat. (Basel), 5, 215-265.

Hartmann, A. F., and Jaudon, J. C. (1937). Hypoglycemia. J. Pediat., 11, 1-36.

Haworth, J. C., and Ford, J. D. (1960). Blood-sugar in infants after lactose feeds. Lancet, 2, 794-797. - and McRae, K. N. (1965). The neurological and developmental
effects of neonatal hypoglycemia. Canad. med. Ass. J., 92, 861-865.

Hicks, S. P. (1953). Developmental brain metabolism. Effects of cortisone, anoxia, fluoroacetate, radiation, insulin, and other inhibitors on the embryo, newborn, and adult. Arch. Path., 55, 302-327.

Jacobson, H. N., and Windle, W. F. (1960). Response of foetal and new-born monkeys to asphyxia. J. Physiol. (Lond.), 153, 447-456.

Komrower, G. M. (1954). Blood sugar levels in babies born of diabetic mothers. Arch. Dis. Childh., 29, 28-33.

Lawrence, R. D., Meyer, A., and Nevin, S. (1942). The rathological changes in the brain in fatal hypcglycaemia. Quart. J. Med., 35, (n. s. 11), 181-201.

Lidz, T., Miller, J. M., Padget, P., and Stedem, A. F. A. (1949). Muscular atrophy and pseudologia fantastica associated with islet cell adenoma of the pancreas. Arch. Neurol. Psychiat. (Chic.), 62, 304-313.

Malamud, N. (1963). In Selective Vulnerability of the Brain in Hypoxaemia, edited by J. P. Schadé and W. H. McMenemey, pp. 211-225. Blackwell, Oxford.

McIlwain, H. (1966). Biochemistry and the Central Nervous System, 3rd ed., p. 6. Churchill, London.

McQuarrie, I. (1954). Idiopathic spontaneously occurring hypoglycemia in infants. Amer. J. Dis. Child., 87, 399-428.

Meyer, A. (1963). In Greenfield's Neuropathology, 2nd ed., by W. Blackwood, W. H. McMenemey, A. Meyer, R. M. Norman, and D. S. Russell, p. 255. Arnold, London.

Moersch, F. P., and Kernohan, J. W. (1938). Hypoglycemia. Neurologic and neuropathologic studies. Arch. Neurol. Psychiat. (Chic.), 39, 242-257.

Mott, J. C. (1961). The ability of young mammals to withstand total oxygen lack. Brit. med. Bull., 17, 144-148.

Naeye, R. L. (1964). Organ composition in newborn parabiotic twins with speculation regarding neonatal hypoglycemia. Pediatrics, 34, 415-418.

- (1965). Malnutrition. Probable cause of fetal growth retardation. Arch. Path., 79, 284-291.

Neligan, G. A., Robson, E., and Watson, J. (1963). Hypoglycaemia in the newborn. A sequel of intrauterine malnutrition. Lancet, 1, $11282-1284$.

Norman, R. M. (1963). In Greenfield's Neuropathology 2nd ed., by W.'Blackwood, W. H. McMenemey, A. Meyer, R. M. Norman, and D. S. Russell. p. 382. Arnold, London.

Palmgren, A. (1948). A rapid method for selective silver staining of nerve fibres and nerve endings in mounted paraffin sections. Acta zool. (Stockh.), 29, 377-392.

Penrose, L. S. (1961). Mongolism. Brit. med. Bull., 17, 184-189.

Ranck, J. B., and Windle, W. F. (1959). Brain damage in the monkey, Macaca mulatta, by asphyxia neonatorum. Exp. Neurol., 1, 130-154.

Reisner, S. H., Forbes, A. E., and Cornblath, M. (1965). The smaller of twins and hypoglycaemia. Lancet, 1, 524-526.

Scopes, J. W. (1964). In Discussion. Proc. roy. Soc. Med., 57, 1063.

Shelley, H. J. (1964). Carbohydrate reserves in the newborn infant. Brit. med. J., 1, 273-275.

—, and Neligan, G. A. (1966). Neonatal hypoglycaemia. Brit. med. Bull., 22, 34-39.

Stevens, J. F. (1965). Biochemical changes in the blood of the newborn. J. med. Lab. Technol., 22, 47-69.

Stief, A., and Tokay, L. (1932). Beiträge zur Histopathologie der experimentellen Insulinvergiftung. Z. ges. Neurol. Psychiat., 139, 434-461.

13, (1935). Weitere experimentelle Untersuchungen über die cerebrale Wirkung des Insulins. Ibid., 153, 561-572.

Tom, M. I., and Richardson, J. C. (1951). Hypoglycaemia from islet cell tumor of pancreas with amyotrophy and cerebrospinal nerve cell changes. J. Neuropath. exp. Neurol., 10, 57-66.

Vrba, R. (1962). Glucose metabolism in rat brain in vivo. Nature (Lond.), 195, 663-665.

Weil, A., Liebert, E., and Heilbrunn, G. (1938). Histopathologic changes in the brain in experimental hyperinsulinism. Arch. Neurol. Psychiat. (Chic.), 39, 467-481.

Winkelman, N. W., and Moore, M. T. (1940). Neurohistopathologic changes with metrazol and insulin shock therapy. An experimental study on the cat. Ibid., 43, $1108-1137$.

Wortis, J., Bowman, K. M., Goldfarb, W., Fazekas, J. F., and Himwich, H. E. (1941). Availability of lactic acid for brain oxidations. J. Neurophysiol., 4, 243-249. 